\title{
Rosemary Lowe-McConnell, obituary
}

\author{
Melanie L. J. Stiassny • Leslie S. Kaufman
}

Received: 25 February 2015 / Accepted: 4 March 2015 / Published online: 21 March 2015

(C) Springer Science+Business Media Dordrecht 2015

Rosemary Helen Lowe-McConnell was born in Liverpool on 24 June 1921 and died peacefully on 22 December 2014 at St. George's Park, Ditchling, England. Despite declining health "Ro", as friends and colleagues around the globe knew her, retained her fabulous sense of humor and famously generous good spirits, graciously entertaining a steady stream of visitors at her Sussex home up until very near the time of her death. Ro was an exceptional woman whose intellectual legacy will long endure, not only in her many scholarly contributions but also very much in the lives and careers of the countless young researchers she inspired to follow in her large ecological and taxonomic footsteps. She led a rich and adventurous life replete with fabulous tales of her time in Africa and South America - often seeming more the life of a character in an Isak Dinesen novel than that of the highly accomplished research scientist and distinguished pioneer in the nascent field of tropical fish ecology that she was. In 1994, this journal published an excellent biography and tribute to Rosemary LoweMcConnell (Bruton 1994), and we recommend reference to that paper for a chronology of her life and

M. L. J. Stiassny $(\bowtie)$

Department of Ichthyology, American Museum of Natural History, New York, NY, USA

e-mail:mljs@amnh.org

L. S. Kaufman

Department of Biology, Boston University, Boston, MA, USA

e-mail: lesk@bu.edu achievements (replete with many charming anecdotes) up until the mid-nineties. Rather than repeat in detail that chronology here we want instead to try and convey the impact that her life has had on our scientific community and the inspiration she gave to the countless students, colleagues, and field workers from all around the globe whose lives she touched.

Much of Ro's early career was spent in East Africa where she undertook a series of foundational studies on the ecology, taxonomy, and fisheries of Africa's iconic food fishes: the tilapias. In 1945, as a young woman of just 24 she left the bucolic English Lake District and her first job as biologist at the Freshwater Biological Association on Windermere for the shores of a much larger, and certainly more challenging, tropical lake in Nyasaland (present day Malawi). There she spent 3 years, working under oftenarduous conditions and mostly alone but for the local guides and fishermen whose skill and knowledge she so greatly appreciated. Her capacities in the field were the stuff of legend - a single woman working alone deep into the tropical night required her to be tough, tenacious and driven, yet she remained so disarmingly likeable that all she achieved, despite the hardships, was simply recounted as "jolly fun". That jolly fun resulted in the ensuing years in the publication of a series of seminal papers on the biology of tilapias and their fisheries.

In 1947 she returned to England to write-up her Malawi report, and just 1 year later was headed back to Africa, this time to Jinja on the Ugandan shores of Lake Victoria. As a founding member of the newly 
formed East African Fisheries Research Organisation (EAFRO), she served at Jinja as a Research Officer in the British Overseas Research Service. Once again her remit was to study the biology and fisheries potential of tilapias in the East African lakes, a task she undertook with remarkable skill and ecological acumen. Life at EAFRO with its constant stream of visiting researchers and excellent staff scientists was extraordinarily stimulating, and as anyone who has had the pleasure of visiting with Ro will know, it was also a time of many droll adventures as she traveled the African bush in her trusty, if less than reliable, Land Rover.

By 1953 she had met and married the geologist Richard McConnell, resigned government service, and moved to the Bechuanaland Protectorate (present day Botswana). Between 1954 and 1956 the McConnells immersed themselves in Botswanian natural history, Richard the geology and Ro, always the inveterate collector, the fishes. Her prized Okavango fish collection is now housed in the Natural History Museum, London, where she was to become a long time Associate. In 1957 Richard was recruited to direct the Geological Survey in British Guiana (Guyana) and Ro was provided research support, plus the princely stipend of one dollar a year, by the Guiana Department of Agriculture and Fisheries to carry out fish surveys in some of the country's most remote and unstudied regions. Once again her work proved foundational, revealing among many other things, the tremendous diversity and ecological complexity of fish communities in the Rupununi-a huge but remote floodplain system at the border of Guyana, Suriname and Brazil. During what she called her "marine transgression" Ro also surveyed, studied, and published on the country's inshore marine fishes.

Richard retired in 1962 and the couple returned to England where Ro became an Associate of the British Museum (Natural History), London. Although she continued to participate in field studies in both South America and Africa, most of the next four decades were spent ensconced in the small office she shared at the "BM" with her friend and mentor Ethelwynn Trewavas, working on her extensive collections and synthesizing years of careful study on two continents. Ro loved the constant flow of visiting students and researchers through the museum's Fish Section. And while this was a period of prodigious productivity for her with the publication of many influential papers and reports, she always had time for others. Whether they were timid young students or the most eminent of visiting dignitaries Ro was unfailingly and incorrigibly warm and welcoming. Her office became the destination in the museum's Fish Section - the place to share the latest research news, exchange ideas, and receive endless and enthusiastic encouragement.

Ro's growing standing as a leader in tropical ecology and fisheries biology, combined with her genius at bringing people and ideas together meant that she was increasingly called upon to organize international meetings, synthesize entire fields in keynote addresses, and to edit numerous symposia and books. Her collaborative works covered topics ranging from speciation in tropical environments to the impacts of man-made lakes on fish community dynamics, and from unifying concepts in ecology to the functioning of freshwater ecosystems. Her years of studying fishes, their ecology, and fisheries biology on two continents gave her a particularly rich perspective, and in 1975 she published the first of three highly influential books, solidifying her place among the founders of the field of tropical fish ecology (LoweMcConnell 1975, 1977, 1987).

Her intellectual inclusive fitness is vast and enduring. The late 1980's saw a resurgent global fascination with the African great lakes region and its fishes. The evolutionary mysteries of the cichlid species flocks were being laid bare by advancing genetic and genomic technologies, drawing a new wave of enthusiasts to East Africa. Meanwhile, the globalization of information, commodities, and environmental impacts had placed Lake Victoria and the African Great Lakes in general front and center in the Anthropocene's litany of mass extinction and rapidly degrading ecosystems. Suddenly, any and all information on the way things had been "in the old days" was of enormous importance, and Ro was our source. She freely offered of her knowledge and well-considered advice to a host of scientists, young and old, on various Great Lakes research projects and governance bodies of the 90's and early 2000's, including the Lake Victoria Research Team, the Lake Victoria Environmental Management Project, the Lake Victoria Fisheries Organization, and the Lake Victoria Species Survival Program (LV-SSP). In 2000, Ro joined us in Jinja for a seminal reassessment of fisheries and fish biodiversity in Lake Victoria. Ro's presence, which she thoroughly enjoyed, sanctified the event, and the 
attendants bent themselves in earnest to the workshop's purpose of scientific review and policy recommendations, mindful of Ro's lifetime effort. The LV-SSP, a captive breeding program practiced by the world's zoos and aquariums, is intended to restore waning endemics to the wild in the greater Lake Vitoria-Kyoga region. These include one of two endemic tilapiines, Oreochromis esculentus, gone from the main lakes but flung across ponds and reservoirs scattered throughout the region. Genetics be damned: without Ro, it would never have been possible to puzzle out where populations were likely to have been native, versus introduced. Whatever reason yet prevails in fish species conservation in the region owes enormously to Ro's deep, quiet wisdom and wry wit. Among Ro's greatest legacies will undoubtedly be her massive contribution to the reestablishment of fishery science in East Africa, and the shining new cadre of African ichthyologists who are carrying that banner today.

In 1997 she was honored with the award of the prestigious Linnean Medal of Zoology by the Linnean Society of London, a society she greatly enjoyed and to which she had years earlier been elected a fellow and served as vice-president. And through the following years, although entering her 80 's Ro continued to contribute to numerous edited volumes, produce insightful book reviews, and after years of urging, spearheaded by her friend and former colleague from the BMNH, Gordon (Gordie) Howes, in her 85th year published a memoir "The Tilapia Trail. The life story of a fish biologist" (Lowe-McConnell 2006). It is a marvelous read, and a wonderful account of a full and adventurous career. The Brazilian ichthyologist Horácio Júlio Júnior prefaced his review of Tilapia Trails with grateful reminiscences of Ro's kindness and influence on his own career and that of many of his South American colleagues (Júlio Júnior 2007). Horácio's words could have been spoken by so many of us, from around the globe to whom Ro has been such a generous supporter and inspirational model.

Although physically unable to get around, as she would have liked, Ro remained thoroughly engaged and actively involved in the lives and work of friends and colleagues, many of whom continued to visit her up until the time of her death. Her career spanned more than 60 years during which time she traveled the globe, made friends wherever she went, and published over 80 scientific papers and books - one of the last publications she co-authored, sadly, was an obituary of her dear friend and neighbor, and colleague of many years, Gordie Howes (Harrison et al. 2013).

Ro truly was a pioneer, a woman working for much of her long and distinguished career in the "man's world" of the British Colonial Service and the mid-20th century scientific establishment. Of course, she would never have dreamt of complaining or considering herself in any way handicapped or hindered, indeed her response to all hardship was supremely understated and always couched in humor. Characteristically, her single comment on the fact that in 1953 when she married Richard McConnell she was forced to resign her EAFRO position due to the Colonial Research Service's anachronistic "marriage bar" was uttered as she received her Linnean Medal of Zoology_ "Not bad for someone who hasn't had a job since 1953!" Not bad indeed Ro, not bad indeed.

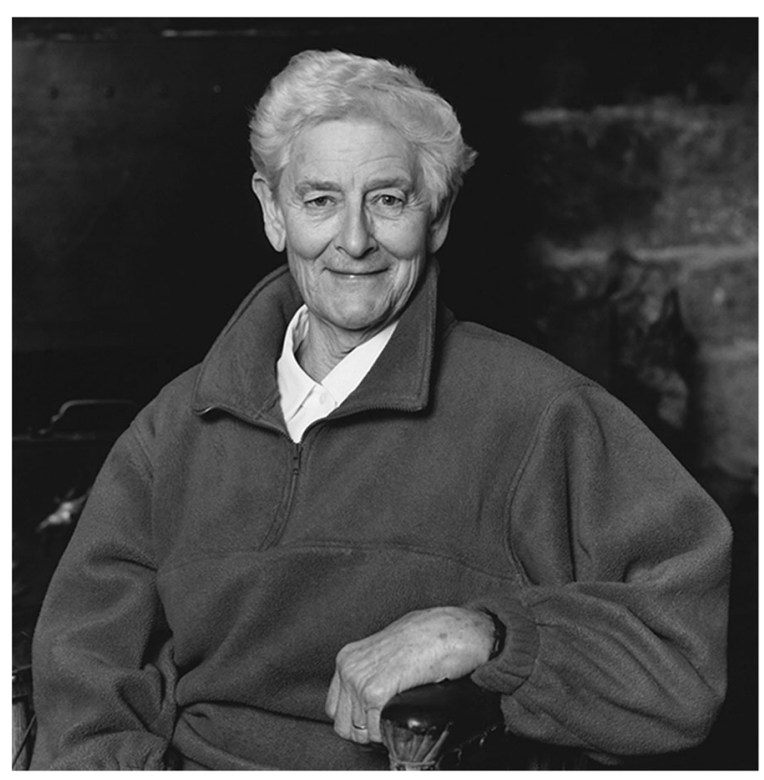

Rosemary Lowe-McConnell (taken in 1994 by family friend and well-known English photographer, Nicholas Sinclair) 


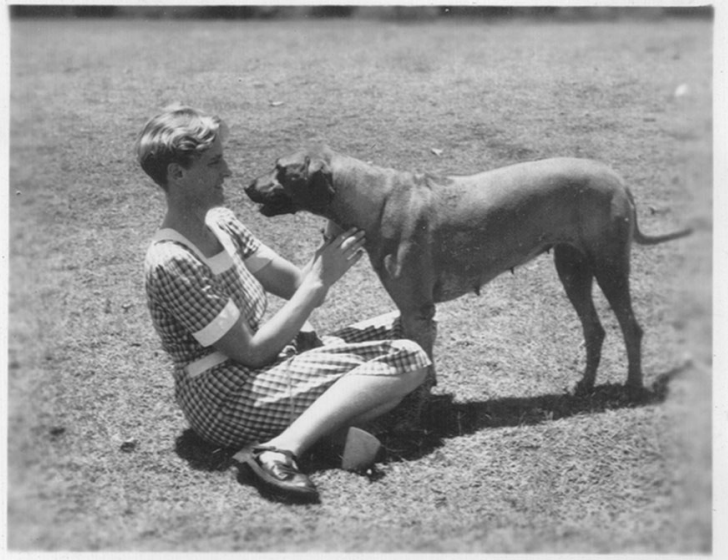

With her dog "Taffy" at Jinja in early 1950s (photo by Ro's friend Peggy Brown)

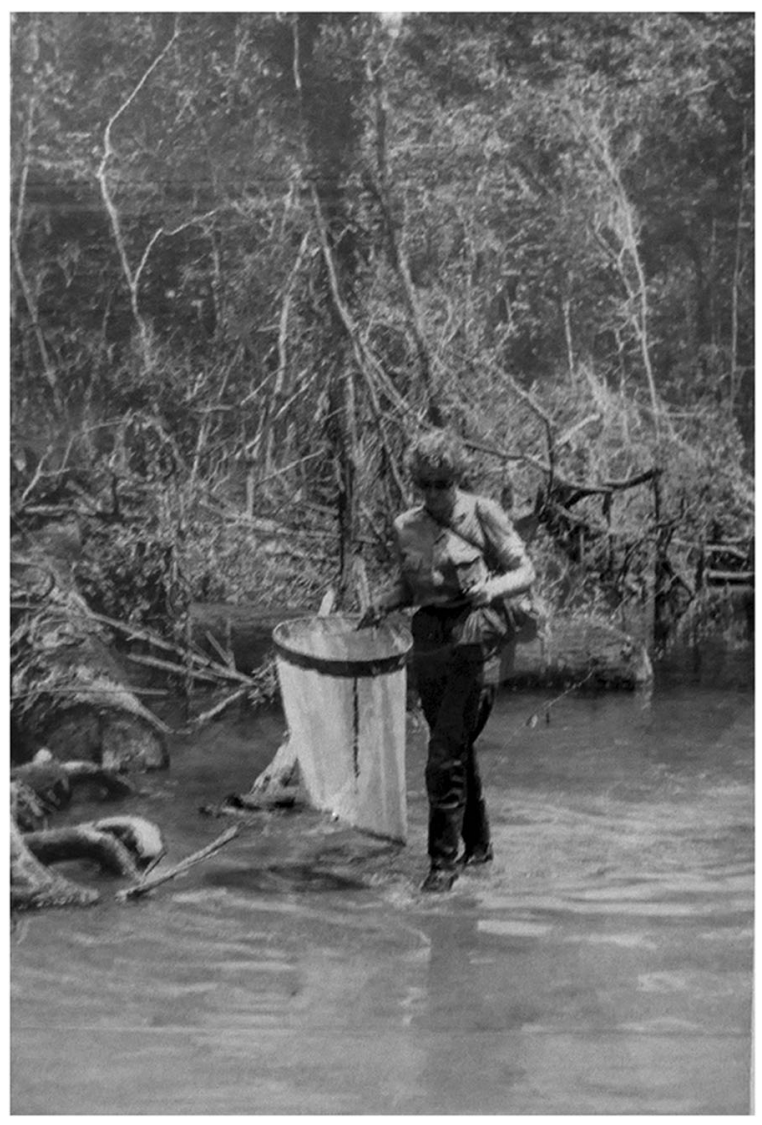

In the water in Guyana, unknown photographer in late 1950s. This picture, a favorite of Ro's, was framed and hung in her apartment in Ditchling.

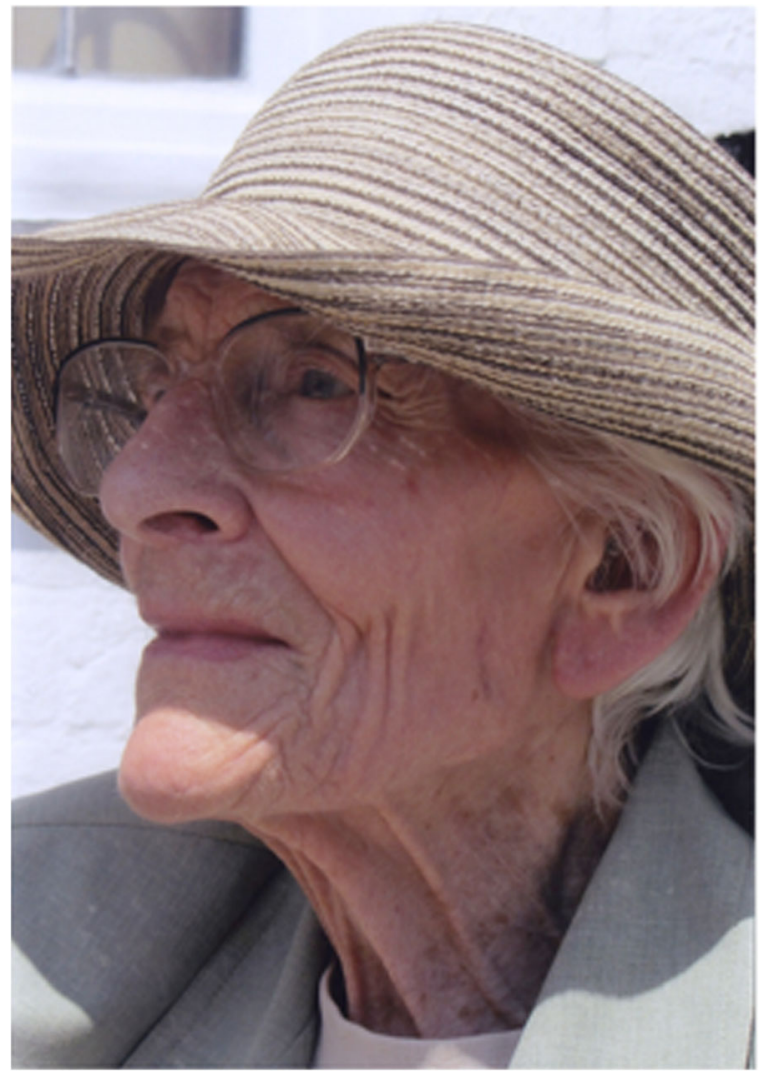

Rosemary Lowe-McConnell. Photo taken by her god daughter, Jennifer Greenwood, after a pub-lunch last year.

\section{References}

Bruton MN (1994) The life and work of Rosemary LoweMcConnell: pioneer in tropical fish ecology. Environ Biol Fish 41:67-80

Harrison I, Evans M, Lowe-McConnell R et al (2013) Obituary. Gordon John Howes 1938-2013 (Fish Systematist). J Fish Biol 83:1085-1093

Júlio Júnior HF (2007) Review of the Tilapia trail. The life story of a fish biologist. Neotrop Ichthyol 5(1):85

Lowe-McConnell R (1975) Fish communities in tropical freshwaters; their distribution, ecology and evolution. Longman, London, $337 \mathrm{pp}$

Lowe-McConnell R (1977) Ecology of fishes in tropical waters. Studies in biology no. 76. Edward Arnold, London, 64 pp

Lowe-McConnell R (1987) Ecological studies in tropical fish communities. Cambridge University Press, Cambridge, 382 pp. (Translated into Portuguese in 1992, with additional chapters on Brazilian fishes)

Lowe-McConnell R (2006) The tilapia trail. The life story of a fish biologist. MPM Publishing, Ascot, 296 pp 